Article

\title{
Social Capital and Sustainable Innovation in Small Businesses: Investigating the Role of Absorptive Capacity, Marketing Capability and Organizational Learning
}

\author{
Lu Xin ${ }^{1}$, Fangcheng Tang ${ }^{1}{ }^{*}$, Shuwei Zhang ${ }^{2}$ and Zhen Pan ${ }^{3}$ \\ 1 The College of Economics and Management, Beijing University of Chemical Technology, \\ Beijing 100029, China; xinlu@mail.buct.edu.cn \\ 2 The College of Economics and Management, Beijing Jiaotong University, Beijing 100044, China; \\ 17113183@bjtu.edu.cn \\ 3 School of Labor and Human Resources, Renmin University of China, Beijing 100872, China; \\ panzhen@ruc.edu.cn \\ * Correspondence: tangfc@mail.buct.edu.cn; Tel.: +86-10-64438793
}

Received: 16 March 2020; Accepted: 28 April 2020; Published: 6 May 2020

\begin{abstract}
Facing resource constraints and fierce competition, it is relatively difficult for small firms to achieve product innovation to gain sustainable development independently. Previous studies have explored the positive relationship between social capital and product innovation, yet there is still a lack of a comprehensive understanding of the underlying mechanism and the boundary conditions. Drawing upon the dynamic capabilities framework, we expect that absorptive capacity and marketing capability will mediate the relationship between social capital and new product development. Moreover, since product innovation is considered a process of learning, we also examine the moderating effects of explorative learning, and exploitative learning within moderated mediation models. Employing a sample of 221 small firms based in China, we find that social capital is indeed positively associated with new product development and is simultaneously fully mediated by absorptive capacity and marketing capability. Furthermore, the impact of absorptive capacity on new product development is amplified when a condition of explorative learning exists. This study, therefore, advances the current understanding on the predictors of innovation and enriches the dynamic capabilities theory, and also provides empirical support for the sustainable development of small firms.
\end{abstract}

Keywords: social capital; new product development; dynamic capabilities; small business; sustainability

\section{Introduction}

It has long been recognized that innovation is significant to the sustainable development of firms due to its contribution to the profitability and long-term continuity of a firm [1]. Threatened by intensifying competition, numerous enterprises are dedicated to sustainable innovation and put new product development at the top of their agendas [2]. Compared with large companies, small businesses have resource disadvantages in innovation and can hardly complete innovation on their own [3]. Therefore, they have an incentive to seek cooperation and many of them leverage social capital to enhance their product innovation, pursuing sustainability $[4,5]$. By participating in social networks, small businesses can acquire innovative technology and external resources to assist their innovation process and reduce barriers to sustainable development [6]. While developing new products, enterprises 
need to acquire new resources from outsiders, and also rely on relational resources to neutralize external threats [7]. Social capital, interpreted as social relationships and managerial connections with outsiders, plays a foundational role in new product development by bringing the firm information benefits and market opportunities [8]. The significant role of social capital in new product development has been recognized [5,9-12]. However, most research simply verifies the direct effect, and only some has attempted to discover the mediating element through a single path with no boundary condition, leading to the lack of a comprehensive understanding [13]. To address the gap, this current study aims to develop an integrated conceptual framework to explain how social capital improves new product development and when these relationships are strengthened so as to provide new empirical support for the sustainable innovation development of small companies.

Flexible capacities benefit small firms over large companies to compensate for certain resource shortcoming [3]. Teece [14] introduced the concept of dynamic capabilities and indicated that a company's innovativeness is constrained by its distinctive capabilities. These capabilities enable companies to protect, deploy and develop resources to sustain innovation in such rapidly changing environments [15]. In contrast with substantive capabilities, which firms originally use to develop new products, dynamic capabilities refer to those abilities that organizations use to reform the way that they develop new products due to knowledge and market dynamism [16]. Therefore, the influence of external and changing resources on new product development largely depends on dynamic capabilities, implying a model of "resource-capability-outcome" [17]. As external connections with outsiders, social capital brings a firm external knowledge and connections to market, which helps the firm to generate dynamic capabilities and reform the way in which it develops new products [18]. Therefore, we suppose that the framework of dynamic capabilities provides an in-depth view that can explain how social capital affects new product development, which may provide new ideas for the sustainable development of small enterprises.

To further advance the understanding of these mechanisms, our research also aims to explore when the impacts of the dynamic capabilities will be strengthened. Based on previous research, there is a strong link between dynamic capabilities and organizational learning [16]. Moreover, organizational learning is of the essence in fostering organizational innovation [19]. However, the role and nature of learning remains relatively limited [20]. New product development is recognized as a learning process that involves exploring new knowledge and exploiting existing knowledge to commercialize their ideas [21]. Therefore, we construct a moderated mediation model to examine the moderating roles of exploratory learning and exploitative learning in the relationship between social capital and new product development in small firms through the mediating roles of dynamic capabilities.

To sum up, this piece of work contributes to the existing literature on social capital and innovation management among small firms in at least three ways. First, based on dynamic capabilities view, it attempts to identify the key dynamic capabilities that mediate the relationship between social capital and new product development. Second, this research aims to deepen the understanding of the strategic role of organizational learning by testing its interaction effect with dynamic capabilities in a moderated mediation model. Thirdly, the study compares the differences between exploratory learning and exploitative learning by examining their moderating effects separately.

\section{Theoretical Background and Hypothesis Development}

\subsection{The Relationship Between Social Capital and New Product Development}

At the firm level, social capital refers to the external resource offered by a firm's network of relationships [22]. The organizational literature generally regards it as a valuable resource that is embedded within, and available through, the network of relationships [23] but also collectively owned by the network members [24]. Nahapiet and Ghoshal [25] illustrated three dimensions of social capital: structural, relational, and cognitive. First, the structural dimension explains who the actor is in contact with and how contact is made; that is, whether network ties exist and what the 
network configuration is. Second, relational capital focuses largely on assets created and leveraged through the network. This dimension is usually linked to trust, reciprocity, obligation, commitment, and so on. Finally, the cognitive dimension refers to resources offering network members shared representations, interpretations, value, and goals. All three dimensions have direct influences on new product development based on both internal and external social relationships [8].

Innovation is closely associated with sustainable development [26], and it is fundamentally a knowledge-intensive process and a collaborative effort [27,28]. When developing a new product, firms need to integrate and combine specialized knowledge from different technology areas, both internally and externally. Social capital could influence this process by developing social networks inside and outside the firm [29]. Specifically, internal social capital refers to linkages among individuals and groups within the organization. A high level of internal social capital often suggests relationships of trust among the employees, which encourages them to actively exchange their ideas and combine different information to promote new product development [27]. At the same time, such high-quality relationships can help achieve meaningful collaborations and foster creativity through interactions among employees for further innovation [30]. Meanwhile, external social capital also exerts an important effect on product innovation by connecting external partners or customers. A high level of external social capital could create a climate of cooperation, trust, and commitment with other firms, which promotes the integration of information and knowledge, assisting product innovation.

Furthermore, as consumer demands become more diverse and product technology becomes more complex, a single firm can hardly master all the required technological knowledge [31]. Adner and Kapoor [32] conducted a 20-month field study in the semiconductor lithography equipment industry and proved the importance of technological interdependence for innovational outcomes. In obtaining access to complementary competences and knowledge from external environment, social capital plays a crucial role in freeing the firm from resource constraints [33]. It also enhances the interactions and communications across organizational boundaries, thereby expanding more channels for innovational resources and simplifying the process of technology imports [34]. With globalization, partners in open innovation may come from different countries, with different industrial background and values, where cognitive social capital is required to support cooperation with shared language and visions [35]. In addition, social capital could also strengthen the connections with clients, assisting firms to seize marketing opportunities and develop new products to satisfy their customers' new demands. This long-term positive relationship with customers may urge enterprises to pay more attention to their customers and implement a customer-oriented development strategy, so as to produce new competitive products.

Since resource limitations are considered the major disadvantage in small firms' innovation [3], social capital is even crucial for them as it can help small firms to integrate and combine various resources both internally and externally, which is beneficial to new product development. Consequently, we propose the following hypothesis:

Hypothesis 1 (H1): social capital is positively related to new product development.

To further reveal the underlying mechanism between social capital and new product development, we propose a moderated mediation model, shown in Figure 1. 


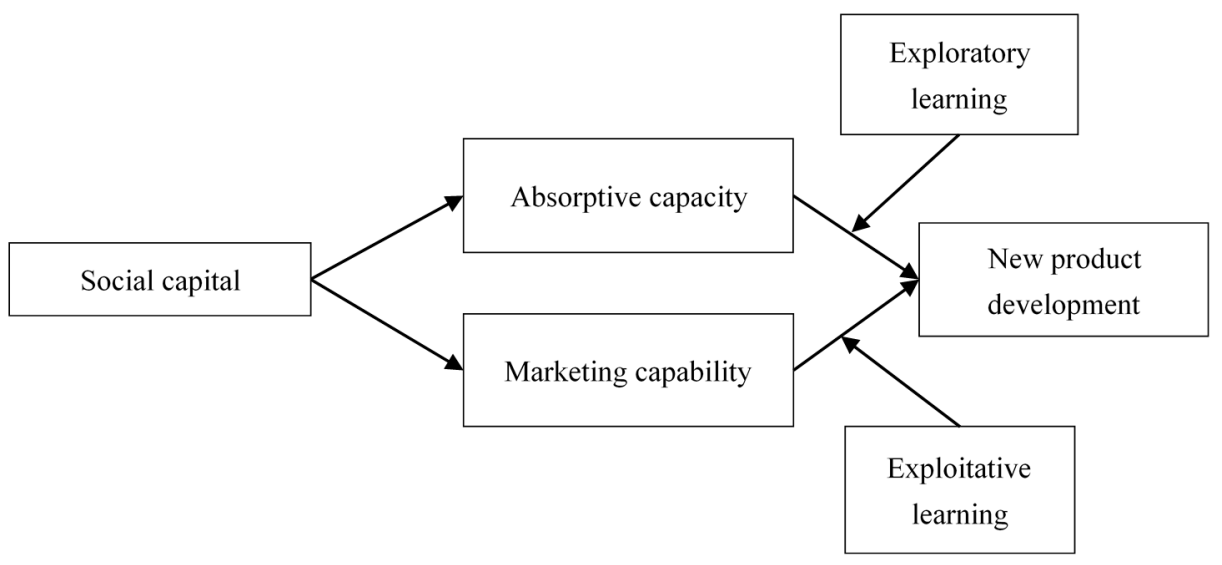

Figure 1. The conceptual model outlined in this paper.

\subsection{Dynamic Capabilities Framework}

Moving beyond the direct impact, some researchers have attempted to discuss the influence of social capital on innovation from different perspectives, ranging from knowledge acquirement and the organizational learning process to creativity [13]. Atuahene-Gima and Murray [8] examined the mediating role of organizational learning capability in the relationship between social capital and new product development with the assumption that new product development was greatly affected by organizational learning capability, which could be informed by social capital. Analogously, Chang et al. [5] proposed a mediation model with creativity as the mediator since they believed that all innovations begin with creative ideas and the generation of the ideas could be benefited by social capital. These studies simply verified a single path at each time with no boundary condition, lacking a comprehensive understanding of the underlying mechanism. According to Teece [15], the framework of dynamic capabilities aims to explain how firms achieve competitive advantage as well as marketplace success with open resources for innovation. Since resources need to be created, deployed, and utilized by firm-level distinct capabilities and then turn into innovational outcomes, we adopt dynamic capabilities theory to explain how social capital could contribute to firms' innovation with a conceptual framework of "resource-capability-outcome" [8].

Capabilities are defined as complex bundles of skills and accumulated knowledge on which enterprises rely to make use of their assets. Dynamic capabilities refer specifically to the capabilities of an organization to purposefully to create, extend, or modify its resource base [36]. Previous studies have shown that social capital play a key role in firms' generation of dynamic capabilities since social capital can help firms to convert the external resources into internal strategic capabilities and achieve sustainable development by the means of managerial communication and technical exchange $[18,37,38]$.

Within the different directions (horizontal vs. vertical) of social network linkages, social capital develops different dynamic capabilities. Specifically, the establishment of horizontal linkages, referring to collaboration ties across the same level of a value chain (e.g., R\&D consortia, patent swaps, technology transfers, or joint ventures) is more useful for technological innovation purposes [39]. In such linkages, firms mainly leverage social networks to acquire technology and knowledge related to innovation, for which we suppose that social capital embedded in horizontal linkages mainly impose an impact on firms' absorptive capacity. By contrast, vertical linkages across different levels of the value chain, such as outsourcing arrangements and customer-supplier relationship, are often developed to better satisfy customers $[39,40]$. Through vertical linkages, firms are more inclined to share market-related information and resources, resulting in a quick sense of new demands and accurate segmentation [41]. As a result, social capital embedded in vertical linkages improve firms' marketing capabilities.

According to Teece [15], the framework of dynamic capabilities aims to explain how firms achieve competitive advantage as well as marketplace success with open resources for innovation, which also means sustainable competitiveness. Since resources need to be created, deployed, and utilized by 
firm-level distinct capabilities and then turn into innovational outcomes, we adopt dynamic capabilities theory to explain how social capital could contribute to firms' innovation with a conceptual framework of "resource-capability-outcome" [8].

Teece [15] claims that dynamic capabilities are required to "adapt to changing customer and technological opportunities". More specifically, as an ability to identify, assimilate, and transform external knowledge, absorptive capacity enables firms to adapt to technological opportunities by increasing the firm's knowledge variety and bringing in new technologies which promotes the feasibility and variability of new products [42,43]. Meanwhile, with a quick and accurate sense of market opportunities, marketing capability allows an enterprise to adapt to changing customers by renewing products timely, and the high sales will in turn motivate new product development [44]. In sum, absorptive capacity pushes the process of new product development by providing the necessary knowledge, technology, and ideas, while marketing capability pulls it from the customer and commercial ends. Analogously, Chesbrough [45] proposes that innovative enterprises use external ideas as well as internal ones and have external paths to the markets, which represents absorptive capacity and marketing capability, respectively.

Therefore, we argue that the absorptive capacity and marketing capability are the main dynamic capabilities that mediate the proposed relationship between social capital and new product development. At the same time, they are crucial capabilities that assist in the sustainable development of small businesses.

\subsection{The Mediating Role of Absorptive Capacity and Marketing Capability}

Absorptive capacity refers to a firm's ability to identify the value of external knowledge, assimilate it into the firm's context, and transform it to commercial ends [46]. Social capital may help a firm to enhance its absorptive capacity by unlocking the access to knowledge [47]. The structural dimension of social capital, acting as information and resource flow, can increase the speed and breadth of the technology-related prior knowledge accumulation [48,49]. With such prior knowledge, a firm is able to identify, understand, and use external knowledge more efficiently, resulting in better and easier assimilation of the knowledge [50]. Meanwhile, relational capital reinforces this positive effect because network members with trust and reciprocal relationship are more willing to share knowledge [51,52]. In addition, given that cognitive capital provides network members with shared language and conduct code, members are easier to present, exchange, adopt, and even combine various ideas, thus improving their absorptive capacity [53].

As a bridge connecting external and internal knowledge, absorptive capacity increases a firm's knowledge variety and facilitates knowledge recombination, which promotes the feasibility and variability of new products [43]. In addition, absorptive capacity helps companies gain external knowledge from customers, competitors, suppliers, and other institutions, which renews their sense and comprehension in the exchange value of the new products so that they can have better selection and retention from potential innovation alternatives [54].

To sum up, in the new product development process, absorptive capacity ensures that small enterprises convert the information and knowledge acquired through social capital into commercial outcomes. Consequently, we propose the following hypothesis:

Hypothesis 2 (H2): absorptive capacity mediates the relationship between social capital and new product development.

Marketing capability enables firms to predict changes in the demand side, as well as establish and maintain durable relationships with customers, suppliers, and channel members [55]. Market knowledge, the basis of marketing capabilities development, is often embedded in social networks $[55,56]$. Without an ongoing and structured pattern of interaction with customers, firms can 
hardly break the barriers to meet customer needs and are unable to share information or exchange knowledge [2].

Social capital will also benefit marketing capabilities by strengthening the relationship with customers and channel members. On the one hand, interactions between a firm and its customers increase customers' acceptance and recognition of the selling firm, which in turn enables a firm to develop and maintain customer relationships effectively [57]. On the other hand, once trust, a critical factor in relational social capital, is built among firms, the networks will become more stable because members are less likely to engage in opportunistic behavior, so that firms can better organize their suppliers, complementors, and distributors to respond to the market and meet consumers' needs quickly [40]. Cognitive social capital provides a shared vision and behavioral norms that promote inter-organizational coordinating and information sharing [58].

Marketing capability is viewed as a platform for innovation and is associated positively with new product development $[57,59]$. The success of new product development depends largely on whether it can create and deliver superior customer value [60]. Representing a quick and accurate sense of market opportunities, marketing capability assists the enterprise to develop new products in line with the markets, customers, and value streams [20]. It increases the success of new products by attracting customers to offer maximal exchange value for the new product. Meanwhile, marketing capabilities enable firms to identify knowledge of market preference, and then transform market knowledge into resources, skills, and activities to shape a new product that meets customers' needs but differs from competitors' offerings, which increases the novelty of a product [61].

In addition, firms with better marketing capability are good at communicating the unique and differentiated benefits of their new products to potential customers, thereby achieving high sales, which in turn promotes new product development [44]. Based on above reasons, we propose:

Hypothesis 3 (H3): marketing capability mediates the relationship between social capital and new product development.

\subsection{The Moderating Role of Organizational Learning}

Organizational learning, a process of acquiring, retaining, and transferring knowledge within an organization, is recognized as crucial in new product development when facing a turbulent and dynamic environment [62]. March [63] first distinguished exploratory learning from exploitative learning, and this is now widely accepted by scholars and practitioners. Exploratory learning concentrates on acquiring and creating new knowledge while exploitative learning focusing on the utilization and transformation of existing knowledge. Previous efforts to understand the role of organizational learning in innovation have mainly focused on its direct impact, resulting in a lack of examinations into its moderating effect [20]. In fact, whether skills and knowledge can affect innovation depends largely on the learning context, because organizational learning represents a firm's new product development attitude and tendency at the strategy level [64].

Both the exploratory and exploitative learning strategies encourage firms to develop new products, but with different mechanisms. With the exploratory learning strategy, firms tend to search for and acquire new knowledge and new techniques far beyond their existing experiences, aiming at developing brand new products [65]. Those firms with higher levels of absorptive capacity fit better with this type of strategy, so the relationship between absorptive capacity and new product development is strengthened. Besides, according to organizational learning theory, a high level of exploratory learning assists firms in absorbing and using external concepts and ideas to enhance product innovation, Hence, exploratory learning strategy and absorptive capacity have an interaction effect on new product development, based on which we propose:

Hypothesis 4 (H4): exploratory learning moderates the relationship between social capital and new product development through the mediating role of absorptive capacity. 
Conversely, the exploitative learning strategy leads firms to maximize the utilization of the firm's current knowledge and techniques, aiming at refining existing products and transferring them to commercial ends [66]. Those firms with a high level of marketing capability have quick and accurate sense of market opportunities as well as an in-depth understanding of current products, which enables them to meet the exploitative learning strategy and further improve the advantages of existing products [67]. Meanwhile, scholars in strategic marketing have paid considerable attention to organizational learning from the perspective of market-driven and market orientation $[68,69]$. The exploitative learning strategy helps enterprises with better marketing capabilities to pay more attention to refining existing products in order to fulfill current customer needs and expand market segments, so we expect that exploitative learning plays a moderating role in the relationship between marketing capability and new product development. Thus:

Hypothesis 5 (H5): exploitative learning moderates the relationship between social capital and new product development through the mediating role of marketing capability.

\section{Methods}

\subsection{Data and Sample}

To empirically test the hypotheses in the moderated mediation model that we developed, we used quantitative data collection methods to get small firms' scores on each variable and examined the relationships between the variables with quantitative data analysis software. Specifically, we conducted questionnaire surveys and collected data from 400 small Chinese firms, the great majority of which were located in Beijing and Hefei, China. We followed three sample criteria: the firms must (1) have fewer than 500 employees; (2) be older than three years; and (3) involve new product or service development activities. Scholars have their own definitions of small business and different standards to classify the size of firms. Following the previous studies on small business like Covin [70], and Audretsch [71], we used the first criterion as the minimum benchmark to select samples. We also took industrial differences into account, so we read company introductions on their official websites or public database to ensure that all the firms in the survey list could be classified as a small business in their own industries. The second criterion was required because the resources and capabilities that we examined (such as social capital and organizational learning) may take a significant time to develop, and firms younger than three years old are less likely to have well-developed social capital and dynamic capabilities [72]. Besides, the sampled firms were also required to be involved in new product or service development activities, so we checked their business descriptions through open databases or the firms' official websites to exclude those firms with no new product development activities. Then, we confirmed the circumstances of the firms matching the selection criteria and finally selected 400 qualified firms. The questionnaires were distributed to the managing directors of these sampled firms, requiring them to organize other relevant persons to fill out the questionnaire. More specifically, to minimize common method bias, we required different respondents to answer different contents of the questionnaire: the CEO on the items about social capital and absorptive capacity, managers of human resources departments on the construct of organizational learning, managers of marketing on the contents of marketing capability, and managers of $R \& D$ on new product development.

The original version of the questionnaire was designed in English on the basis of prior research. To ensure conceptual equivalence, two translators were asked to twice translate the questionnaire into Chinese and then back to English, and opinion variances were eliminated through discussion [73]. We first carried out in-depth interviews with 10 firms to make sure whether the questionnaire was complete, relevant, and effective, and whether the hypotheses adequately described managers' experiences; we subsequently conducted a pilot study of 30 samples to confirm whether there was any items that confused the respondent, but also to check the reliability and validity of the questionnaire. Drawing upon the results of the pretests, we revised our questionnaire and then hand-delivered it to the 
sample firms. We received 290 responses, with the response rate of $72.50 \%$. Of these, 44 questionnaires had incomplete answers and were thus removed, and finally 221 responses were left for data analysis. The specific sample characteristics are presented in Table 1.

Table 1. Sample characteristics $(N=221)$.

\begin{tabular}{ccc}
\hline Characteristic & Sample & Proportion \\
\hline Age & & \\
3-5 years & 54 & $24.43 \%$ \\
6-10 years & 116 & $52.49 \%$ \\
Over 11 years & 51 & $23.08 \%$ \\
\hline Industry & & \\
Telecommunication & 16 & $7.24 \%$ \\
Textile, furniture, and handicraft manufacturing & 16 & $7.24 \%$ \\
Automobile and automotive parts & 11 & $5.21 \%$ \\
Information technology & 35 & $15.84 \%$ \\
Chemical, metal, and material products & 30 & $13.58 \%$ \\
Real estate and construction & 39 & $17.65 \%$ \\
Pharmaceutical health and manufacturing & 13 & $5.88 \%$ \\
Wholesale and retail sales & 16 & $7.24 \%$ \\
Finance and consulting & 19 & $8.60 \%$ \\
Other & 26 & $11.76 \%$ \\
\hline
\end{tabular}

\subsection{Measures}

\subsubsection{New Product Development}

We argue that new product development performance should not only involve the creativity of the new product, but also include the market repercussions. Therefore, we followed the prior work of Im and Workman [74] and Carosn, Wu, and Moore [75] and adapted their items to measure both the new product creativity and new product success. New product creativity consists of six items, which mainly assess how novel the new product is and whether it brings new ideas to the industry [74]. In terms of new product success, five items were used to measure the extent to which new products exceed expected market returns [75]. The overall Cronbach's alpha coefficient of the whole scale was 0.90 .

\subsubsection{Social Capital}

Nahapiet and Ghoshal [25] identify three dimensions of social capital, which are widely approved by other researchers. Our study followed this division and used a scale (Cronbach's $\alpha=0.84$ ) containing three subscales with three items each to measure the structural capital, relational capital, and cognitive capital respectively [25]. More specifically, the structural capital subscale adapted from Campion, Medsker, and Higgs [76] assesses the diversity of expertise, skills, and backgrounds of the firm and its partners. These items captured the level of standardized and customized information exchanged between the sample firm and its partners. The relational capital subscale adapted from Inkpen and Tsang [58] reflects the mutual trust and compliance with commitments. These items reflected the level of trust between the sample firm and its partners at the level of commitment. The cognitive capital subscale which was designed on the prior work of Nahapiet and Ghoshal [25], and Cohen and Levinthal [46], measured the shared value, language, and behavioral norms, focusing on the level of agreement between the sample firm and its partners around their willingness to change for one other.

\subsubsection{Absorptive Capacity}

Following the definition of absorptive capacity given by Cohen and Levinthal [46], we used a 15-item scale (Cronbach's $\alpha=0.82$ ) to measure it along three dimensions: identification, assimilation, and exploitation. The scale was designed based on the prior studies of Cohen and Levinthal [46], 
Jansen et al. [77], and Flatten et al. [78]. Among which, four items of identification dimension assess firms' ability to discover useful knowledge from external information. The five items of assimilation dimension required the respondents to report the degree to which firms can understand new knowledge through imitation, experience, and shared language. The six items of exploitation dimension reflected the extent to which firms share knowledge acquired from external environment and apply this to production activities.

\subsubsection{Marketing Capability}

The ten items used to measure marketing capability were chose from the scale developed by Song et al. [61], and Chen, Li, and Arnold [79]. We used these items to assess the extent to which firms had a good understanding of the market; established durable relationships with customers, suppliers, and channel members; and were able coordinate marketing activities. The Cronbach's alpha of the scale was 0.87 .

\subsubsection{Organizational Learning}

We used the scale developed by Atuahene-Gima and Murray [8] to separately measure exploratory learning and exploitative learning. Five items were used to assess exploratory learning, and aimed to reflect the extent to which firms were concerned about new information and technology trends in the industry. Five items were used to measure exploitative learning, asking respondents to indicate the degree to which firms applied existing technology to the new product development process. The Cronbach's alpha of the two sub-scales were 0.83 and 0.81 , respectively.

\subsubsection{Control Variables}

We included the age of the firm as a control variable because older firms with an experience advantage might have a better understanding of the market, yet younger firms might be more open to new knowledge [72].

\section{Results}

\subsection{Reliability and Validity}

To examine the internal consistency of the variables, we used SPSS 23.0 to carry out the Cronbach's coefficient analysis. The statistical results show that all the Cronbach's coefficient alphas ranged from 0.805 to 0.891 were higher than 0.7 ; thus, the scales showed high reliability. We also used AMOS 21.0 to conduct a confirmatory factor analysis to test whether the variables in the model are mutually distinct. The result showed that the scale with five variables had the best goodness of fit value $\left(\chi^{2} / \mathrm{df}=5.82\right.$, $\mathrm{IFI}=0.83, \mathrm{CFI}=0.90, \mathrm{RMSEA}=0.08, \mathrm{SRMR}=0.05)$, which indicated that the model had acceptable discriminant validity.

\subsection{Descriptive Statistics}

Table 2 provides the descriptive statistics and correlations among the factors. As is shown, social capital was positive related to absorptive capacity $(r=0.73, p<0.01)$, marketing capability $(r=0.67$, $p<0.01)$, new product development $(r=0.45, p<0.01)$, exploratory learning $(r=0.44, p<0.01)$, and exploitative learning $(r=0.47, p<0.01)$; absorptive capacity was positive related to new product development $(r=0.57, p<0.01)$; marketing capability was positive related to new product development $(r=0.50, p<0.01)$; exploratory learning was positive related to new product development $(r=0.57$, $p<0.01)$; and exploitative learning was positive related to new product development $(r=0.69, p<0.01)$. The results of correlation analyses generally supported the positive relations among social capital, absorptive capacity, marketing capability, exploratory learning and exploitative learning, and new product development. 
Table 2. Descriptive statistics and correlation coefficients.

\begin{tabular}{cccccccccc}
\hline & Mean & S.D. & $\mathbf{1}$ & $\mathbf{2}$ & $\mathbf{3}$ & $\mathbf{4}$ & $\mathbf{5}$ & $\mathbf{6}$ & $\mathbf{7}$ \\
\hline 1 Firm age & 9.74 & 9.17 & - & & & & & & \\
2 Social capital & 4.74 & 0.97 & $0.15^{*}$ & - & & & & & \\
3 Absorptive capacity & 4.76 & 0.92 & $0.16^{*}$ & $0.73^{* *}$ & - & & & & \\
4 Marketing capability & 5.12 & 0.99 & $0.23^{* *}$ & $0.67^{* *}$ & $0.63^{* *}$ & - & & & \\
5 New product development & 4.59 & 0.91 & $0.16^{* *}$ & $0.45^{* *}$ & $0.46^{* *}$ & $0.45^{* *}$ & - & & \\
6 Exploratory learning & 4.58 & 0.83 & $0.25^{* *}$ & $0.48^{* *}$ & $0.33^{* *}$ & $0.74^{* *}$ & $0.57^{* *}$ & - \\
7 Exploitative learning & 4.45 & 0.93 & $0.16^{*}$ & $0.37^{* *}$ & $0.36^{* *}$ & $0.39^{* *}$ & $0.69^{* *}$ & $0.52^{* *}$ & - \\
\hline
\end{tabular}

Notes. $N=221,{ }^{*} p<0.05,{ }^{* *} p<0.01,{ }^{* * *} p<0.001$.

\subsection{Testing Multiple Mediating Effects}

To examine whether absorptive capacity and marketing capability mediate the relationship between social capital and new product development, we adopted a hierarchical regression analysis. In this way, examinations of four equations were essential [80]: the first was the regression of social capital to new product development, the second and third were the regressions of the social capital to the mediator variables (absorptive capacity and marketing capability), and the fourth was the regression of both social capital and the mediator variables (absorptive capacity and marketing capability) to new product development. We could only explain the existence of mediating effects under the conditions that all these effects were significant, but the addition of mediators reduced the significance of the association between social capital and new product development [81].

The results shown in Table 3 indicated support for Hypothesis 1 with social capital positively and significantly related to new product development $(\beta=0.43, p<0.001)$. Additionally, the results revealed that both the absorptive capacity $(\beta=0.44, p<0.001)$ and marketing capability $(\beta=0.20$, $p<0.01)$ served as significant predictors for new product innovation. The positive relationship between absorptive capacity $(\beta=0.48, p<0.001)$ and marketing capability $(\beta=0.23, p<0.01)$ was also significant after controlling the effect of social capital. Furthermore, when putting the independent variable and the mediators into the equation, the effect of social capital $(\beta=0.07, \mathrm{~ns})$ was no longer significant, suggesting that the effect was fully mediated by absorptive capacity and marketing capability. Thus, Hypotheses 2 and 3 were fully supported.

Table 3. Hierarchical regressions.

\begin{tabular}{lcccc}
\hline \multicolumn{1}{c}{ Variables } & AC & MC & \multicolumn{2}{c}{ New Product Development } \\
\hline Constant & $1.39^{* * *}$ & $1.81^{* * *}$ & $2.61^{* * *}$ & $1.55^{* *}$ \\
Firm age & 0.05 & $0.15^{*}$ & 0.05 & 0.01 \\
Social capital & $0.72^{* * *}$ & $0.65^{* * *}$ & $0.43^{* * *}$ & 0.07 \\
Absorptive capacity & & & & $0.48^{* * *}$ \\
Marketing capability & & & & $0.24^{* *}$ \\
R-squared & 0.53 & 0.47 & 0.19 & 0.36 \\
Adjusted R2 & 0.53 & 0.46 & $0.19^{* * *}$ & 0.35 \\
F-value & $114.40^{* * *}$ & $92.24^{* * *}$ & $23.51^{* * *}$ & $27.20^{* * *}$ \\
\hline
\end{tabular}

Notes. $N=221,{ }^{*} p<0.05,{ }^{* *} p<0.01,{ }^{* * *} p<0.001$.

\subsection{Testing Moderated Mediating Effects}

Our model also tested whether exploratory learning and exploitative learning, respectively, moderated the relationship between social capital and new product development through absorptive capacity and marketing capability. According to Hayes [80], we tested two moderated mediation models, with exploratory learning and exploitative learning as moderators. To support the existence of moderated mediating effects, the indirect effects should vary as a function of the level of the moderator.

Tables 4 and 5 present the results of the bootstrap moderated mediation analysis of the two models. In terms of the moderating role of exploratory learning, the interaction between absorptive 
capacity and exploratory learning was statistically significant $(B=0.20, S E=0.08, t=2.47, p<0.01)$. Furthermore, at different levels of exploratory learning, the indirect effects of social capital on new product development through absorptive capacity were significant but displayed significant differences (see Figure 2). As shown in Table 4, when the level of exploratory learning was high, $B=0.38, S E=0.09$, $95 \% \mathrm{CI}=(0.22,0.57)$; when it was low, $B=0.16, S E=0.06,95 \% \mathrm{CI}=(0.08,0.31))$. Above, Hypothesis 4 was indicated to be valid.

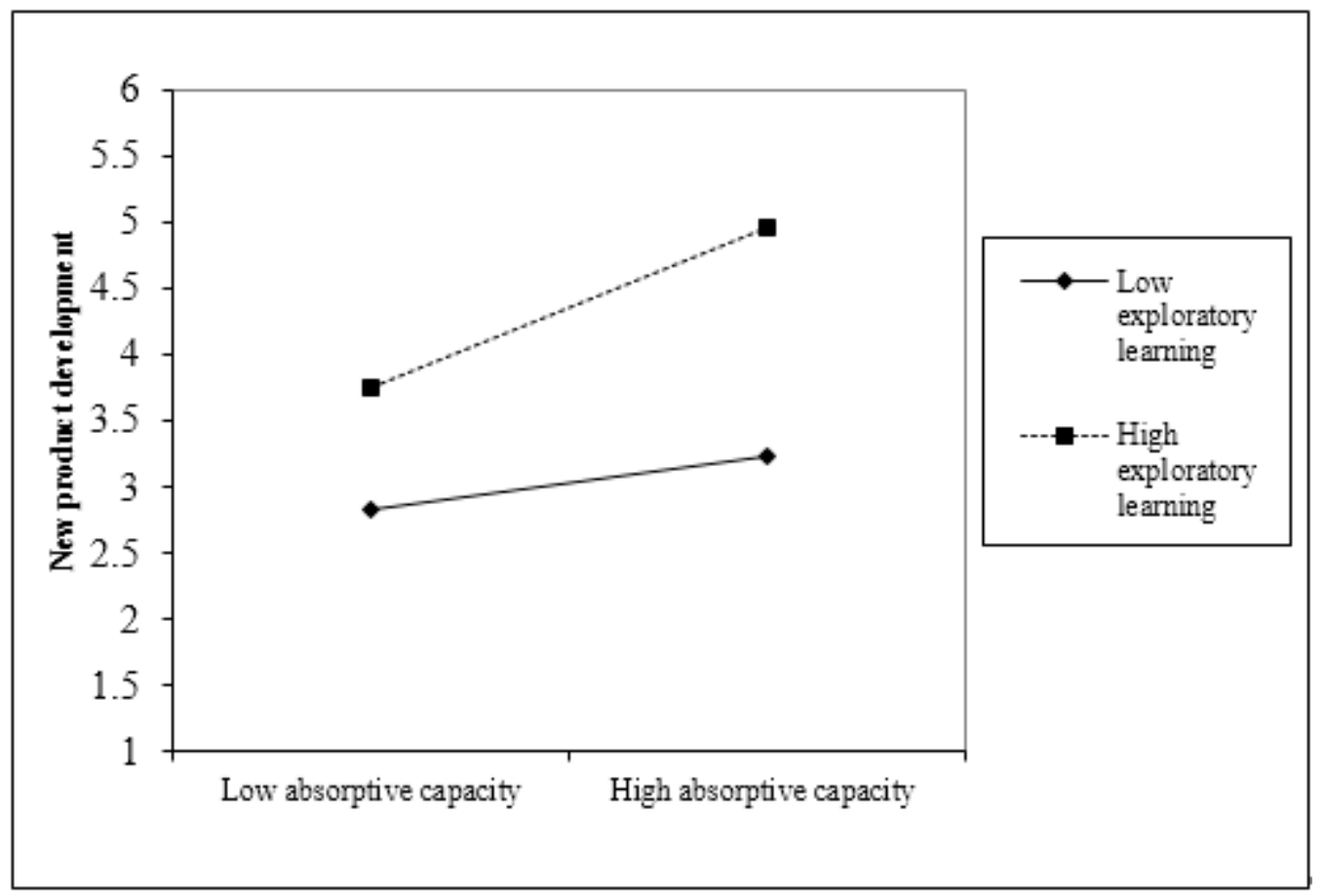

Figure 2. The moderating effect of exploratory learning on the relationship between absorptive capacity and new product development.

Table 4. Bootstrap moderated mediation analysis: exploratory learning as moderator.

\begin{tabular}{|c|c|c|c|c|c|c|}
\hline & & & B & \multicolumn{2}{|c|}{$\mathrm{SE}$} & $\mathbf{t}$ \\
\hline \multicolumn{3}{|c|}{ Constant } & 4.13 & \multicolumn{2}{|c|}{0.38} & 10.76 \\
\hline \multicolumn{3}{|c|}{ Absorptive capacity } & 0.40 & \multicolumn{2}{|c|}{0.09} & $4.43 * * *$ \\
\hline \multicolumn{3}{|c|}{ Marketing capability } & 0.27 & \multicolumn{2}{|c|}{0.10} & $2.84 *$ \\
\hline \multicolumn{3}{|c|}{ Social capital } & 0.09 & \multicolumn{2}{|c|}{0.08} & 1.16 \\
\hline \multirow{3}{*}{\multicolumn{3}{|c|}{$\begin{array}{c}\text { Exploratory learning } \\
\text { Absorptive capacity * exploratory learning } \\
\text { R-squared }\end{array}$}} & 0.99 & \multicolumn{2}{|c|}{0.10} & $9.87^{* * *}$ \\
\hline & & & 0.20 & \multicolumn{2}{|c|}{0.08} & $2.47 *$ \\
\hline & & & & & & 0.50 \\
\hline \multicolumn{3}{|c|}{ F-value } & & & & $38.04^{* * *}$ \\
\hline \multirow{2}{*}{\multicolumn{2}{|c|}{ Direct effect }} & Effect & SE & $\mathrm{t}$ & LLCI & ULCI \\
\hline & & 0.09 & 0.08 & 1.16 & -0.06 & 0.24 \\
\hline \multirow{4}{*}{$\begin{array}{l}\text { Conditional } \\
\text { indirect } \\
\text { effect(s) }\end{array}$} & & Exploratory learning & Effect & Boot SE & Boot LLCI & Boot ULCI \\
\hline & \multirow{3}{*}{$\begin{array}{l}\text { Absorptive } \\
\text { capacity }\end{array}$} & -0.0 .78 & 0.16 & 0.06 & 0.08 & 0.31 \\
\hline & & 0.00 & 0.27 & 0.07 & 0.16 & 0.40 \\
\hline & & 0.78 & 0.38 & 0.09 & 0.22 & 0.57 \\
\hline
\end{tabular}

Notes. $N=221,{ }^{*} p<0.05,{ }^{* *} p<0.01,{ }^{* * *} p<0.001$. LLCI, lower limit confidence interval; ULCI, Upper limit confidence interval. 
Table 5. Bootstrap moderated mediation analysis: exploitative learning as moderator.

\begin{tabular}{cccc}
\hline & B & SE & t \\
\hline Constant & 4.15 & 0.38 & 10.97 \\
Absorptive capacity & 0.30 & 0.09 & $3.41^{* * *}$ \\
Marketing capability & 0.07 & 0.08 & 0.84 \\
Social capital & 0.09 & 0.08 & 1.08 \\
Exploitative learning & 0.63 & 0.07 & $9.33^{* * *}$ \\
Marketing capability * exploitative learning & 0.02 & 0.06 & 0.40 \\
R-squared & & & 0.47 \\
F-value & & & $31.14^{* * *}$ \\
\hline
\end{tabular}

Notes. $N=221,{ }^{*} p<0.05,{ }^{* *} p<0.01,{ }^{* * *} p<0.001$.

As for the moderating role of exploitative learning, the results (see Table 5) showed that the interaction between marketing capability and exploitative learning $(B=0.02, S E=0.06, t=0.40$, ns) was not significant, which implied that Hypothesis 5 was rejected. The overall testing results are shown in Figure 3.

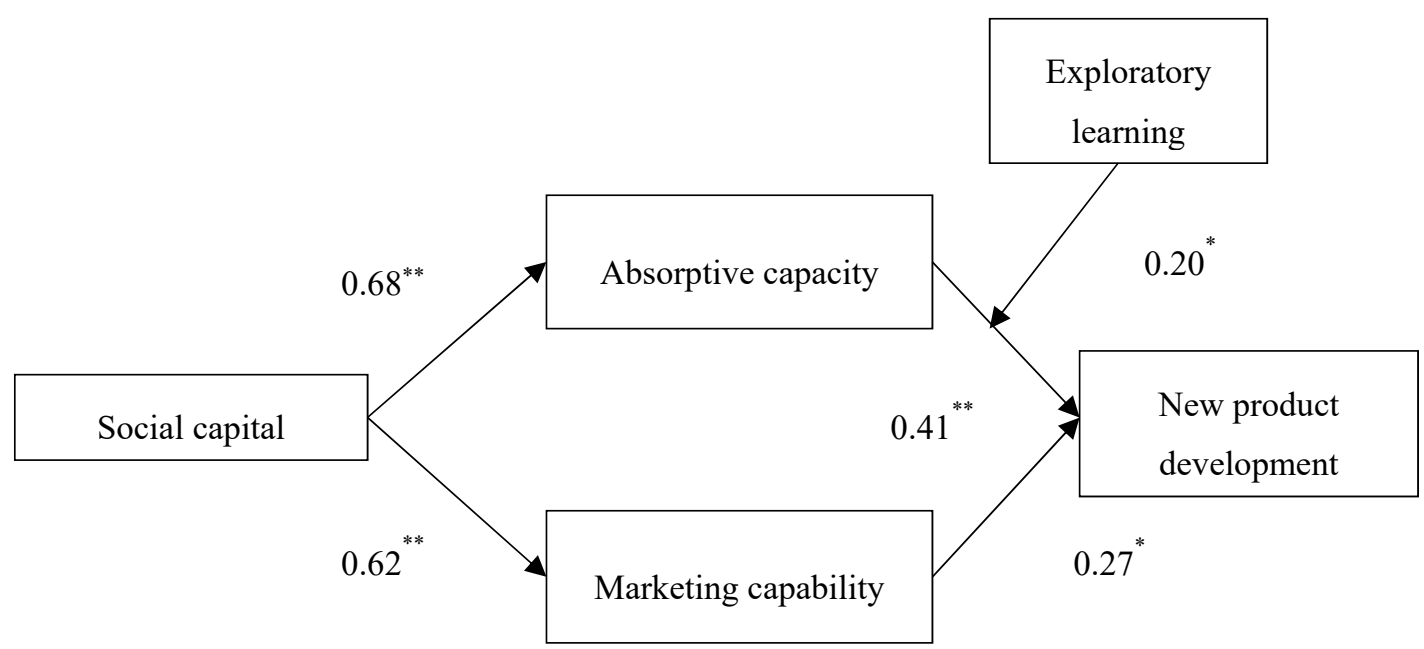

Figure 3. Test of model.

\section{Discussion}

\subsection{Theoretical and Managerial Implications}

Drawing on the dynamic capabilities view, we construct a model of resource-capability-outcome to examine the multiple mediating roles of absorptive capacity and marketing capability in the relationship between social capital and new product development. First, our results reinforce the significance of social capital in generating firms' dynamic capabilities [18,38]. Second, the mediating role of marketing capability and absorptive capacity, which has been thoroughly examined in this study, contributes to capability-based theory [14]. The findings provide evidence for the importance of dynamic capabilities as fundamental explanations of the superior product innovation resulting from social capital. Furthermore, the full mediation effects, rather than partial ones, support Chesbrough's [45] view that absorbing external ideas and establishing external paths to the markets are two major capabilities for innovative enterprises.

In contrast with previous research identifying mediators through a single approach $[5,12]$, this study provides a more comprehensive understanding with an integrated conceptual framework. On the one hand, social capital unlocks access to external knowledge that results in better absorptive capability and further promotes the creativity and success of new products. On the other hand, marketing capability enhanced through the networks with outsiders ensures the creativity and success of new product by shaping the new product and attracting customers. Our findings contribute to 
the literature on social capital and address calls to better understand how social capital affects new product development [5,12].

Although an increasing number of researchers have recognized the importance of learning in new product development, its moderating effect remains not well understood [20]. In this study, we find that exploratory learning positively moderates the relationship between absorptive capacity and new product development, contributing to the theoretical and empirical development of organizational learning in the context of open innovation. This indicates that exploratory learning and absorptive capacity have interplay effects on product innovation. With a better exploratory learning context and more attention paid to exploratory learning strategy, it is easier and quicker for enterprises to identify, absorb, and assimilate knowledge. In turn, greater absorptive capacity promotes more opportunities for learning from outsiders. By contrast, our study shows that exploitative learning has no moderating effect in the relationship between marketing capability and new product development. Regardless of how well a firm utilizes its existing knowledge, the influence of marketing capability on new product development will not be strengthened. However, the results contribute to the literature on organizational learning by supporting the distinction between exploratory learning and exploitative learning at the moderating level [63].

This study offers some crucial practical implications for practitioners. First, we provide them with empirical evidence that social capital help enhance small firms' dynamic capabilities, involving absorptive capacity and marketing capability, which further fosters innovativeness and sustainability of small organizations. Facing the dramatic changing environment, small firms should put more effort into raising and utilizing dynamic capabilities to enhance their sustainability. The results suggest that managers should reinforce their marketing capability by establishing long-term relationships with clients to gain more profit from their new products. Meanwhile, through horizontal social network linkages with other firms, all sorts of resources could be exchanged, ensuring that small firms improve their absorptive capacity and maintain sustainable innovation. Second, we find that the relationship between absorptive capacity and new product development is strengthened when small firms adopt an exploratory learning strategy, which implies that managers should pay more attention to exploratory learning strategy to maintain sustainable innovation.

\subsection{Limitations and Concluding Remarks}

Unfortunately, inconsistent with our hypotheses, the results show that exploitative learning has no moderating effect on the relationship between marketing capability and new product development. Thus, we advocate for further research to discover the moderators that strengthen the effects of marketing capability on product innovation. Additionally, since the design of this study cannot support any causal conclusions for the relationships among these variables [82], further research should adopt a more rigorous design, such as a longitudinal design, to test the causal effects. Moreover, the self-report measurements may not reflect the real situation [83], which means that the results may have some inaccuracies, such as social desirability bias [84]. Although this empirical study was carried out with a relatively large sample, the results were still influenced by individual factors [85]. Employees may over-report the company's social capital, marketing capabilities, or new product success, increasing the error of the results. Finally, as the results were based on a sample of Chinese industrial firms, different cultural and industrial factors may also influence the generalizability of the current results. Specifically, cultural differences may affect the formation of social capital [86], and then affect the mechanism of social capital's function. At the same time, the industrial context of firms may also influence the impact of social capital on small firms' new product development performance [87]. Therefore, whether the current findings could be directly transferred to industrial firms in other countries or service sector awaits future investigation. This study used questionnaire surveys to collect data, which is a quantitative methodology with a relative higher level of objectivity. The relationships between the variables were tested based on scales which provided an empirical basis for the research and it is replicable for future researchers measuring the same variables through 
standardized questionnaires [88]. Moreover, this research revealed the mechanisms between social capital and new product development within a moderated mediation model and examined the relationships between the variables. Future studies could focus on one or two of the linkages in order to provide a deeper understanding, using qualitative research methods such as case study or interviews.

In conclusion, we believe that social capital is the basis for forming dynamic capabilities that further result in innovative outcomes. Recognizing the trend of open innovation, both scholars and business practitioners should pay more attention to external resources. Among the kinds of dynamic capabilities, absorptive capacity and marketing capability dominate and play full mediating roles in the relationship between social capital and new product development. Furthermore, the influence of absorptive capacity on new product development is positively moderated by exploratory learning. Thus, this study advances current understanding on the predictors of product innovation and enriches dynamic capabilities theory.

Author Contributions: Conceptualization, L.X. and F.T.; methodology, S.Z.; software, S.Z.; validation, L.X. and F.T.; formal analysis, L.X.; investigation, F.T.; resources, Z.P.; data curation, L.X.; writing-original draft preparation, L.X. and S.Z.; writing - review and editing, L.X. and Z.P.; visualization, Z.P.; supervision, F.T.; project administration, F.T.; funding acquisition, L.X. and F.T. All authors have read and agreed to the published version of the manuscript.

Funding: This study was funded by: (1) National Natural Science Fund of China (NSFC), grant number "71532003"; (2) China Postdoctoral Science Foundation, grant number "2019M660429".

Conflicts of Interest: The authors declare no conflict of interest.

\section{References}

1. Blum-Kusterer, M.; Hussain, S.S. Innovation and corporate sustainability: An investigation into the process of change in the pharmaceutical industry. Bus. Strategy Environ. 2001, 10, 300-316. [CrossRef]

2. Park, K.M.; Chintagunta, P.K.; Suk, I. Capital market returns to new product development success: Informational effects on product market advertising. J. Mark. Res. 2019, 56, 37-56. [CrossRef]

3. Bos-Brouwers, H. Corporate sustainability and innovation in SMEs: Evidence of themes and activities in practice. Bus. Strategy Environ. 2009, 19, 417-435. [CrossRef]

4. Freel, M.S. Patterns of innovation and skills in small firms. Technovation 2005, 25, 123-134. [CrossRef]

5. Chang, S.C.; Tein, S.W.; Lee, H.M. Social capital, creativity, and new product advantage: An empirical study. Int. J. Electron. 2010, 8, 43-55.

6. Dosi, G. Sources, procedures, and microeconomic effects of innovation. J. Econ. Lit. 1988, 26, 1120-1171.

7. Barney, J. Firm Resources and Sustained Competitive Advantage. J. Manag. 1991, 17, 99-120. [CrossRef]

8. Atuahene-Gima, K.; Murray, J.Y. Exploratory and exploitative learning in new product development: A social capital perspective on new technology ventures in China. J. Int. Mark. 2007, 15, 1-29. [CrossRef]

9. Adler, P.S.; Kwon, S.W. Social capital: Prospects for a new concept. Acad. Manag. Rev. 2002, 27, 17-40. [CrossRef]

10. Dyer, J.H.; Hatch, N.W. Relation-specific capabilities and barriers to knowledge transfers: Creating advantage through network relationships. Strateg. Manag. J. 2006, 27, 701-719. [CrossRef]

11. Luca, L.M.D.; Atuahenegima, K. Market knowledge dimensions and cross-functional collaboration: Examining the different routes to product innovation performance. J. Mark. 2007, 71, 95-112. [CrossRef]

12. Zaheer, A.; Bell, G.G. Benefiting from network position: Firm capabilities, structural holes, and performance. Strateg. Manag. J. 2005, 26, 809-825. [CrossRef]

13. Dost, M.; Badir, Y.; Ali, Z.; Tariq, A. The impact of intellectual capital on innovation generation and adoption. J. Intellect. Cap. 2016, 17, 675-695. [CrossRef]

14. Teece, D.J.; Pisano, G.; Shuen, A. Dynamic capabilities and strategic management. Strateg. Manag. J. 1997, 18, 509-533. [CrossRef]

15. Teece, D.J. Explicating dynamic capabilities: The nature and micro foundations of (sustainable) enterprise performance. Strateg. Manag. J. 2007, 28, 1319-1350. [CrossRef]

16. Prashantham, S.; Zahra, S.A. Social Capital Types and Internationalization: A Study of Indian Software SMEs. Adv. Inst. Manag. Res. Pap. 2006, 45, 1-43. [CrossRef] 
17. Helfat, C.E.; Peteraf, M.A. The dynamic resource-based view: Capability lifecycles. Strateg. Manag. J. 2003, 24, 997-1010. [CrossRef]

18. Helfat, C.E.; Martin, J.A. Dynamic Managerial Capabilities: A Perspective on the Relationship between Managers, Creativity, and Innovation in Organizations; Oxford University Press: Oxford, MI, USA, 2015; pp. 421-429.

19. Backmann, J.; Hoegl, M.; Cordery, J.L. Soaking it up: Absorptive capacity in interorganizational new product development teams. J. Prod. Innov. Manag. 2015, 32, 861-877. [CrossRef]

20. Weerawardena, J.; Mort, G.S.; Salunke, S.; Knight, G.; Liesch, P.W. The role of the market sub-system and the socio-technical sub-system in innovation and firm performance: A dynamic capabilities approach. J. Acad. Mark. Sci. 2015, 43, 221-239. [CrossRef]

21. Edmondson, A.C.; Nembhard, I.M. Product development and learning in project teams: The challenges are the benefits. J. Prod. Innov. Manag. 2009, 26, 123-138. [CrossRef]

22. Rodrigo-Alarcon, J.; Garcia-Villaverde, P.M.; Ruiz-Ortega, M.J.; Parra-Requena, G. From social capital to entrepreneurial orientation: The mediating role of dynamic capabilities. Eur. Manag. J. 2018, 36, 195-209. [CrossRef]

23. Granovetter, M.S. Problems of Explanation in Economic Sociology. Networks and organizations: Structure, Form, and Action; Harvard Business School Press: Boston, MA, USA, 1992; pp. 25-56.

24. Bourdieu, P. The Forms of Capital. Handbook of Theory and Research for the Sociology of Education; Greenwood: New York, NY, USA, 1986; pp. 241-258.

25. Nahapiet, J.; Ghoshal, S. Social capital, intellectual capital, and the organizational advantage. Acad. Manag. Rev. 1988, 23, 242-266. [CrossRef]

26. Paramanathan, S.; Farrukh, C.; Phaal, R.; Probert, D. Implementing industrial sustainability: The research issues in technology management. $R$ D Manag. 2004, 34, 527-537. [CrossRef]

27. Alguezaui, S.; Filieri, R. Investigating the role of social capital in innovation: Sparse versus dense network. J. Knowl. Mang. 2010, 14, 891-909. [CrossRef]

28. Subramaniam, M.; Youndt, M.A. The influence of intellectual capital on the types of innovative capabilities. Acad. Manag. J. 2005, 48, 450-463. [CrossRef]

29. Cuevas-Rodríguez, G.; Cabello-Medina, C.; Carmona-Lavado, A. Internal and external social capital for radical product innovation: Do they always work well together? Br. J. Manag. 2014, 25, 266-284. [CrossRef]

30. Chen, M.; Chang, Y.; Hung, S. Social capital and creativity in R\&D project teams. $R$ D Manag. 2008, 38, 21-33.

31. Iansiti, M.; Levien, R. Strategy as ecology. Harv. Bus. Rev. 2004, 82, 68-78.

32. Adner, R.; Kapoor, R. Innovation Ecosystems and Innovator's Outcomes: Evidence from the Semiconductor Lithography Equipment Industry; INSEAD, 1962-2004; Unpublished working paper.

33. Martínez-Cañas, R.; Sáez-Martínez, F.J.; Ruiz-Palomino, P. Knowledge acquisition's mediation of social capital-firm innovation. J. Knowl. Manag. 2012, 16, 61-76. [CrossRef]

34. Tsai, W.; Ghoshal, S. Social capital and value creation: The tole of intrafirm networks. Acad. Manag. J. 1998, 41, 464-476.

35. Lenart-Gansiniec, R. Crowd Capital-Conceptualization Attempt. Int. J. Contemp. Hosp. Manag. 2016, 15, 29-57.

36. Helfat, C.E.; Finkelstein, S.; Mitchell, W.; Peteraf, M.; Singh, H.; Teece, D.; Winter, S.G. Dynamic Capabilities: Understanding Strategic Chance in Organizations; Blackwell Press: Oxford, MI, USA, 2007.

37. Lawson, B.; Tyler, B.B.; Cousins, P.D. Antecedents and consequences of social capital on buyer performance improvement. J. Oper. Manag. 2008, 26, 446-460. [CrossRef]

38. Zahra, S.A.; George, G. Absorptive capacity: A review, reconceptualization, and extension. Acad. Manag. Rev. 2002, 27, 185-203. [CrossRef]

39. Kotabe, M.; Swan, K.S. The role of strategic alliance in high technology new product development. Strateg. Manag. J. 1995, 16, 621-636. [CrossRef]

40. Bellamy, M.A.; Ghosh, S.; Hora, M. The influence of supply network structure on firm innovation. J. Oper. Manag. 2014, 32, 357-373. [CrossRef]

41. Carey, S.; Lawson, B.; Krause, D.R. Social capital configuration, legal bonds and performance in buyer-supplier relationships. J. Oper. Manag. 2011, 29, 277-288. [CrossRef]

42. Daghfous, A. Organizational learning, knowledge and technology transfer: A case study. Learn. Organ. 2004, 11,67-83. [CrossRef] 
43. Taylor, A.; Greve, H.R. Superman or the fantastic four? Knowledge combination and experience in innovative teams. Acad. Manag. J. 2006, 49, 723-740. [CrossRef]

44. Vorhies, D.W.; Morgan, R.E.; Autry, C.W. Product-market strategy and the marketing capabilities of the firm: Impact on market effectiveness and cash flow performance. Strateg. Manag. J. 2009, 30, 1310-1334. [CrossRef]

45. Chesbrough, H.W. Open Business Models: How to Thrive in the New Innovation Landscape; Harvard Business Press: Boston, MA, USA, 2006.

46. Cohen, W.M.; Levinthal, D.A. Absorptive capacity: A new perspective on learning and innovation. Adm. Sci. Q. 1990, 35, 128-152. [CrossRef]

47. Hughes, M.; Morgan, R.E.; Ireland, R.D.; Hughes, P. Social capital and learning advantages: A problem of absorptive capacity. Strateg. Entrepreneurship J. 2014, 8, 214-233. [CrossRef]

48. Puranam, P.; Chaudhuri, S.S. Integrating acquired capabilities: When structural integration is (un)necessary. Organ. Sci. 2009, 20, 313-328. [CrossRef]

49. Volberda, H.W.; Foss, N.J.; Lyles, M.A. Absorbing the concept of absorptive capacity: How to realize its potential in the organization field. Organ. Sci. 2010, 21, 931-951. [CrossRef]

50. Knockaert, M.; Spithoven, A.; Clarysse, B. The impact of technology intermediaries on firm cognitive capacity additionality. Technol. Forecast. Soc. Chang. 2014, 81, 376-387. [CrossRef]

51. Blyler, M.; Coff, R.W. Dynamic capabilities, social capital, and rent appropriation: Ties that split pies. Strateg. Manag. J. 2003, 24, 677-686. [CrossRef]

52. Koka, B.R.; Prescott, J.E. Strategic alliances as social capital: A multidimensional view. Strateg. Manag. J. 2002, 23, 795-816. [CrossRef]

53. Widen-Wulff, G.; Ginman, M. Explaining knowledge sharing in organizations through the dimensions of social capital. J. Inf. Sci. 2004, 30, 448-458. [CrossRef]

54. Vasconcelos, A.C.; Martins, J.T.; Ellis, D.; Fontainha, E. Absorptive capacity: A process and structure approach. J. Inf. Sci. 2018, 43, 1647-1666. [CrossRef]

55. Day, G.S. The capabilities of market-driven organizations. J. Mark. 1994, 58, 37-52. [CrossRef]

56. Murray, J.Y.; Gao, G.Y.; Kotabe, M. Market orientation and performance of export ventures: The process through marketing capabilities and competitive advantages. J. Acad. Mark. Sci. 2011, 39, 252-269. [CrossRef]

57. Chen, Y.C.; Li, P.C.; Evans, K.R.; Arnold, T.J. Interaction orientation and product development performance for Taiwanese electronics firms: The mediating role of market-relating capabilities. J. Prod. Innov. Manag. 2017, 34, 13-34. [CrossRef]

58. Inkpen, A.; Tsang, E.W. Social capital, networks and knowledge transfer. Acad. Manage. Rev. 2005, 30, 146-165. [CrossRef]

59. Comstock, B.; Gulati, R.; Liguori, S.A. Unleashing the power of marketing. Harv. Bus. Rev. 2010, 88, 90-98.

60. Slater, S.F.; Narver, J.C. Market orientation and the learning organization. J. Mark. 1995, 59, 63-74. [CrossRef]

61. Song, M.; Benedetto, C.A.D.; Nason, R.W. Capabilities and financial performance: The moderating effect of strategic type. J. Acad. Mark. Sci. 2007, 35, 18-34. [CrossRef]

62. Vieira, A.C.; Machado, A.; Tomanari, G.Y. The context effect as interaction of temporal generalization gradients: Testing the fundamental assumptions of the learning-to-time model. Behav. Pro. 2013, 95, 18-30. [CrossRef]

63. March, J.G. Exploration and exploitation in organizational learning. Organ. Sci. 1991, 2, 171-187. [CrossRef]

64. Chandy, R.K.; Tellis, G.J. Organizing for radical product innovation: The overlooked role of willingness to cannibalize. J. Mark. Res. 1998, 35, 474-487. [CrossRef]

65. Martini, A.; Neirotti, P.; Appio, F.P. Knowledge searching, integrating and performing: Always a tuned trio for innovation? Long Range Plann. 2017, 50, 200-220. [CrossRef]

66. Ze, R.; Kun, Z.; Boadu, F.; Yu, L. The effects of boundary-spanning search, network ties, and absorptive capacity for innovation: A moderated mediation examination. Sustainability 2018, 10, 3980. [CrossRef]

67. Li, Y.T.; Yeh, C.C. The supplement of lactobacillus for women. Taiwan. J. Obstet. Gynecol. 2017, 56, 123. [CrossRef] [PubMed]

68. Kohli, A.K.; Jaworski, B.J. Market Orientation: The construct, research propositions, and managerial implications. J. Mark. 1990, 54, 1-18. [CrossRef]

69. Sinkula, J.M.; Baker, W.E.; Noordewier, T.G. A framework for market-based organizational learning: Linking values, knowledge, and behavior. J. Acad. Mark. Sci. 1997, 25, 305-318. [CrossRef] 
70. Covin, J.G.; Slevin, D.P. Strategic management of small firms in hostile and benign environments. Strateg. Manag. J. 1989, 10, 75-87. [CrossRef]

71. Ackermann, S.; Audretsch, D.B. The Economics of Small Firms: A European Challenge; Springer Science \& Business Media: Berlin, Germany, 2013.

72. Yli-Renko, H.; Autio, E.; Sapienza, H.J. Social capital, knowledge acquisition, and knowledge exploitation in young technology-based firms. Strateg. Manag. J. 2011, 22, 587-613. [CrossRef]

73. Hoskisson, R.E.; Eden, L.; Lau, C.M.; Wright, M. Strategy in emerging economies. Acad. Manag. J. 2000, 43, 249-267.

74. Im, S.; Workman, J.P. Market orientation, creativity, and new product performance in High-Technology Firms. J. Mark. 2004, 68, 114-132. [CrossRef]

75. Carson, S.J.; Wu, T.; Moore, W.L. Managing the trade-off between ambiguity and volatility in new product development. J. Prod. Innov. Manag. 2012, 29, 1061-1081. [CrossRef]

76. Campion, M.A.; Medsker, G.J.; Higgs, A.C. Relations between work group characteristics and effectiveness: Implications for designing effective work groups. Pers. Psychol. 1993, 46, 823-847. [CrossRef]

77. Jansen, J.J.P.; Van Den Bosch, F.A.J.; Volberda, H.W. Managing potential and realized absorptive capacity: How do organizational antecedents matter? Acad. Manag. J. 2005, 48, 999-1015. [CrossRef]

78. Flatten, T.C.; Greve, G.I.; Brettel, M. Absorptive capacity and firm performance in SMEs: The mediating influence of strategic alliances. Eur. Manag. Rev. 2011, 8, 137-152. [CrossRef]

79. Chen, Y.C.; Li, P.C.; Arnold, T.J. Effects of Collaborative Communication on the Development of Market-Relating Capabilities and Relational Performance Metrics in Industrial Markets. Ind. Mark. Manag. 2013, 42, 1181-1191. [CrossRef]

80. Hayes, A.F. Introduction to mediation, moderation, and conditional process analysis: A regression-based approach. J. Educ. Meas. 2013, 51, 335-337.

81. Baron, R.M.; Kenny, D.A. The moderator-mediator variable distinction in social psychological research: Conceptual, strategic, and statistical considerations. J. Pers. Soc. Psychol. 1986, 51, 1173-1183. [CrossRef] [PubMed]

82. Saris, W.E.; Gallhofer, I.N. Design, Evaluation, and Analysis of Questionnaires for Survey Research; John Wiley \& Sons: New York, NY, USA, 2014.

83. Peterson, R.A.; Kerin, R. The Quality of Self-Report Data: Review and Synthesis; American Marketing Association: Chicago, IL, USA, 1981.

84. Sudman, S.; Bradburn, N.M. Response Effects in Surveys; Aldine Publishing Company: Chicago, IL, USA, 1974.

85. Klein, K.J.; Kozlowski, S.W. Multilevel Theory, Research, and Methods in Organizations: Foundations, Extensions, and New Directions; Jossey-Bass: San Francisco, CA, USA, 2000.

86. Ji, Y.G.; Hwangbo, H.; Yi, J.S.; Rau, P.P.; Fang, X.; Ling, C. The influence of cultural differences on the use of social network services and the formation of social capital. Intl. J. Hum. Comput. Interact. 2010, 26, 1100-1121. [CrossRef]

87. Stam, W.; Arzlanian, S.; Elfring, T. Social capital of entrepreneurs and small firm performance: A meta-analysis of contextual and methodological moderators. J. Bus. Ventur. 2014, 29, 152-173. [CrossRef]

88. Groves, R.M.; Fowler, F.J., Jr.; Couper, M.P.; Lepkowski, J.M.; Singer, E.; Tourangeau, R. Survey Methodology; John Wiley \& Sons: New York, NY, USA, 2011.

(C) 2020 by the authors. Licensee MDPI, Basel, Switzerland. This article is an open access article distributed under the terms and conditions of the Creative Commons Attribution (CC BY) license (http://creativecommons.org/licenses/by/4.0/). 